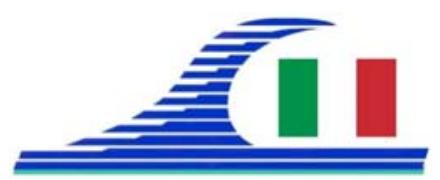

\title{
Lime treatment procedures for the reuse of dredged marine
} sediments

\section{Giacomo RUSSO $^{1}$, Dimitri DENEELE ${ }^{2}$, Paolo CROCE ${ }^{1}$, Giuseppe MODONI $^{1}$}

1. University of Cassino and Southern Lazio, Department of Civil and Mechanical Engineering, Via G. Di Biasio 43, 03043 Cassino (FR), Italy.

giarusso@unicas.it

2. Université de Nantes, Institut de Materiaux Jean Rouxel,

2 rue de la Houssinière, BP 32229, 44322 Nantes cedex3, France.

\begin{abstract}
:
An experimental research has recently been performed for developing an original sediment management and reuse procedure, consisting in the following operations: dredging of the sediments from the seabed, pumping of the dredged soil to the shoreline, reduction of water content by desiccation, addition of lime for stabilisation, placement in the embankment. In the paper some results of the experimental laboratory work carried out to highlight the effectiveness of the procedure have been reported. The suitability of lime treatment has been investigated with particular reference to the high initial water content of the soil. The efficiency of the improvement has been investigated by mechanical testing after short term since lime addition.
\end{abstract}

Keywords: Marine sediments, Maritime works, Reuse of sediments, Lime treatment, Mechanical behaviour.

\section{Introduction}

One of the main problems of the construction of large port infrastructures is the management of a very large amount of dredged material, especially if it has mechanical properties not suitable for its reuse as construction material. This material could represent an important resource if it is appropriately worked and/or improved in order to be reused for construction purposes. A valid possibility from the environmental and economical point of view can be represented by the reuse of such soils by lime stabilisation. The stabilisation of soils with lime is a well known technique widely used in the practice, whose effects on the natural soils have been studied since the late 50s (CLARE \& CRUCHLEY, 1957; GLENN \& HANDY, 1963; DIAMOND \& KINTER, 1965; EADES \& GRIM, 1966). Lime stabilization may represent a good opportunity also for the construction of structural parts of the earthworks (e.g. road, railway embankments, earth dams). In the recent last decades, great emphasis has been placed on applications of the improvement technique in order to reduce the quantity of waste material to be placed in landfills (CROCE \& RUSSO, 2001). 
Côtes méditerranéennes menacées :

Risques et défis dans le contexte du changement climatique

In the paper some results of an experimental study on lime stabilisation of dredged marine sediments have been reported. The improvement technique has been selected as suitable technique for reusing the dredged sediments as construction material for the docks of a major maritime infrastructure project.

\section{Case study}

For the construction of a large port an innovative procedure aimed to reuse the marine sediments as construction material has been designed. The huge amount of dredged sediments having mechanical properties not suitable as construction material in their natural state, and the long distance of quarries from the construction site, induced the designers to plan lime treatment to improve the dredged materials.

In Figure 1 the sequence of procedure for reusing the dredged soil has been represented. The material is excavated by a cutter suction dredger and pumped to specific soil treatment ponds nearby the shoreline. An additional amount of water is given to the natural soil before pumping (i.e. water content between $100 \%$ and $250 \%$ ), in order to reduce the resistance within the pipelines and the loss of hydraulic head. The pumped slurry is then discharged in the ponds where it experiences a rough separation of the solid fraction from water. The method used for discharging the slurry is referred to as dry stacking (GLENISTER \& ABBOTT 1989; SOFRA \& BOGER 2001), consisting of pumping a thickened slurry from a given discharge point on the dike perimeter into the disposal area. The thickened slurry forms a "tongue" extending at a gentle slope from the dike toward the centre of the impoundment area. The pumped material flows along the slopes at relatively low velocities, thus enhancing the deposition of the solid fraction and the flow of water to a draining channel. When the slurry reaches a depth of about one meter near the dike and extends about hundred meters toward the centre of the area, the discharge port is closed, an adjacent discharge port is opened, and the process is repeated. This process continues for multiple discharge ports around the pipeline. By the time one cycle is completed, the initial layer is exposed to the atmospheric agents (sun irradiation and ventilation) for a time sufficient to further reduce its water content. The desiccation process is continued until the water content of the soil approaches lower values, appropriately set as target water content values to perform the lime treatment. The lime treated soil must then be left some more time (curing time) in the ponds to activate the chemical reactions before excavation and transportation to the embankment area. Part of the treated soil material has to be placed below the sea level (a and b zones in Figure 2). After placement, the material experiences a consolidation process induced by the self-weight of the submerged strata and by the weight of the superimposed layers, before reaching its final physical and mechanical state. Another part (zone c in Figure 2) is placed above the sea level and mechanically compacted. 


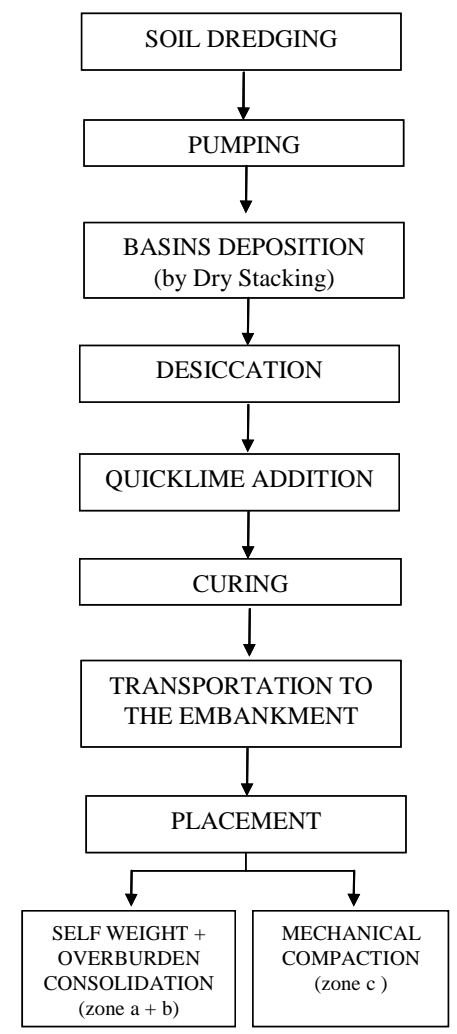

Figure 1. Flow chart of the construction process.

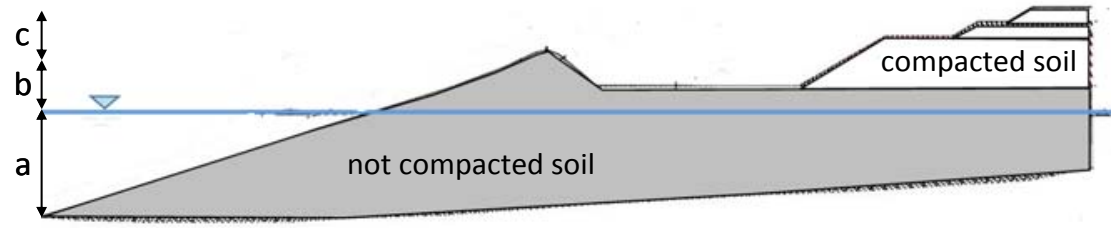

Figure 2. Embankment section.

\section{Experimental study on lime treatment}

The marine sediments have been characterized by means of microstructural and physical analyses. From the $\mathrm{X}$ ray analysis the sample is formed by quartz, calcite and clinochlore. The organic matter (measured by means of Loss-On-Ignition procedure) was found equal to $3.29 \%$. The sulphate content of the soil resulted equal to $0.11 \%$. The main physical properties of the not treated dredged have been reported in Table 1 . The sediment is composed by $18 \%$ of sand, $52 \%$ of silt and $30 \%$ of clay.

Table 1. Physical properties of sediments.

\begin{tabular}{ll}
\hline Specific gravity & 2.71 \\
Liquid Limit & $43 \%$ \\
Plastic Limit & $22 \%$ \\
Plasticity Index & $21 \%$ \\
\hline
\end{tabular}


Côtes méditerranéennes menacées :

Risques et défis dans le contexte du changement climatique

Measurements of the Initial Consumption of Lime (ICL) were performed in order to assess the suitability of the sediment to lime treatment according to ASTM D4972 (ASTM, 1998). The addition of $3 \%$ of quicklime was found sufficient to increase the $\mathrm{pH}$ to 12.4 (pH of lime-saturated water) and then selected for lime treatment.

Oedometer tests were performed on not treated and treated samples cured for increasing time intervals. Curing was performed by sealing the wrapped samples in plastic airtight containers. Samples were prepared at initial water content of $\mathrm{w}=40 \%$ (degree of saturation $S r=1.0$, initial void ratio equal to $e_{0}=1.0$ ) and then placed in the oedometer mould without compaction. The initial water content is the target water content value to perform the lime treatment after desiccation during the construction process. In Figure 3 the one dimensional compressibility curve of the not treated sample has been compared with those pertaining to the treated samples cured for increasing time intervals (namely $0,3,7,14$ and 28 days). The overall volume strains of the stabilised samples are relevantly reduced, and an increase of the yielding stress has been detected for stabilised samples at each curing time selected.

Undrained shear tests were performed on not treated and treated samples by means of a laboratory miniature vane shear tester. High initial water contents were investigated in order to assess the effectiveness of the treatment even in the case in which the treatment with lime was performed prior to the completion of the drying process of the sediments. The choice of very short curing times is connected with the need of minimize the curing time of the treated soil in the ponds. The samples were prepared at increasing initial water contents ( $\mathrm{w}=40 \%, 50 \%, 60 \%$, and $80 \%)$ and cured for $0,1,2$ and 3 days. In Figure 4 the average measured values of the undrained shear strength have been represented as a function of the initial water contents and curing times, and compared with the not treated samples values. For lower initial water contents (i.e., w=40\%), the increase of cu after addition of lime is relevant, with an average value several times higher than the not treated one just at the very short term (i.e. 0 days of curing). At increasing curing times further increase of $\mathrm{c}_{\mathrm{u}}$ is detected but corresponding to lesser increments. For higher initial water contents (i.e., w=50\%) it is still detected an increase of undrained shear strength, relevant for applicative issues but reduced in value. The increase of $c_{u}$ with curing time is markedly reduced. At very high water contents (i.e., $\mathrm{w}=80 \%$ ) the beneficial short term effects induced by the addition of lime on undrained shear strength are negligible because of the very reduced values of this parameter. 


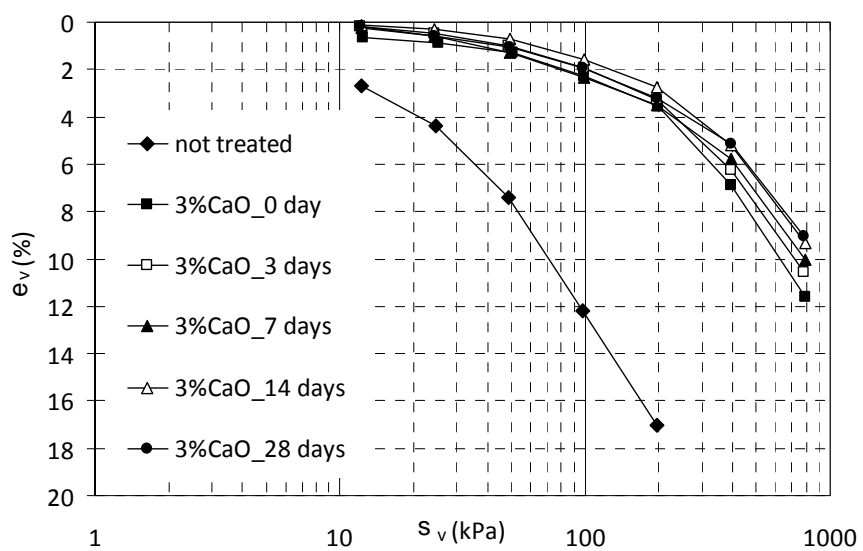

Figure 3. 1D compression behaviour of not treated and lime treated samples.

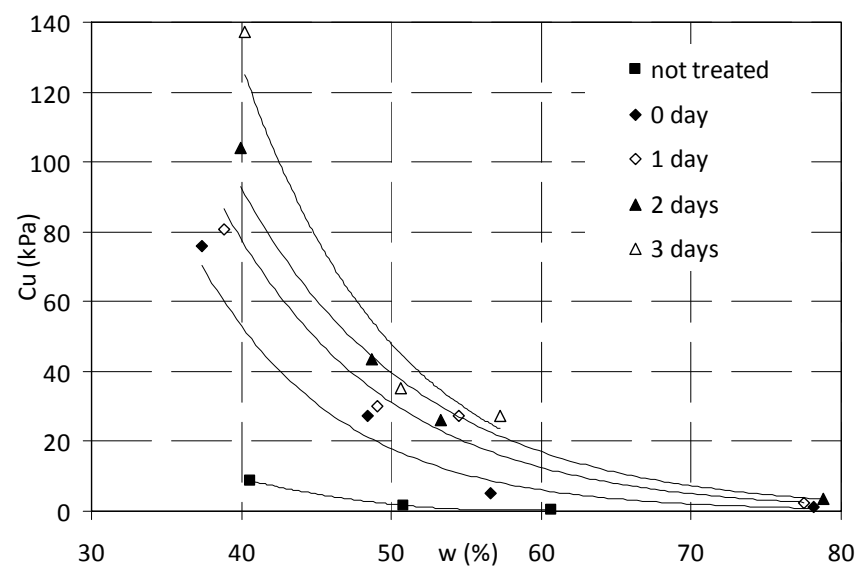

Figure 4. Undrained shear strength of not treated and lime treated samples.

\section{Conclusions}

The experimental work reported in this paper has been focused on lime treatment of dredged marine sediments. The improvement technique has been selected as suitable for the reuse of dredged soils for the construction of a large port infrastructure. The assessment of the suitability of soil to lime stabilisation technique, the setting of treatment parameters and the characterization of the mechanical behaviour of the treated soil in the very short term are the main aspects of the work.

The results allowed the setting of the construction procedure at the design stage. The duration of the desiccation process of dredged sediments in the ponds, the selection of the water content at which lime treatment has to be performed, the curing time of the treated sediments inside the ponds were relevant construction parameters selected after the response of the experimental work described in the paper. 
Côtes méditerranéennes menacées :

Risques et défis dans le contexte du changement climatique

\section{References}

ASTM -American Society for Testing and Materials- (1998). D4972 - Standard test method for $\mathrm{pH}$ of Soils. Annual Book of ASTM standard, Section 4 Construction, Vol. 04.09.

CLARE K.E., CRUCHLEY A.E. (1957). Laboratory experiments in the stabilization of clays with hydrated lime. Géotechnique, Vol. 7(2), pp 97-111.

http://dx.doi.org/10.1680/geot.1957.7.2.97

CROCE P., RUSSO G. (2001). Reimpiego dei terreni di scavo mediante stabilizzazione a calce, Proceedings 21st AGI CNG, Patron Editore, Padova, pp 211-216.

DIAMOND S., KINTER E.B. (1965). Mechanisms of soil lime stabilization: an interpretive review. Highway Research Record, Vol. 92, pp 83-96.

EADES J.L., GRIM R.E. (1966). A quick test to determine lime requirements for lime stabilization. Highway Research Record, Vol. 139, pp 61-72.

GLENISTER D., ABBOTT T. (1989). Dewatering and Disposal of Fine Bauxite Residue, Dewatering Technology and Practice, Brisbane.

GLENN G.R., HANDY R.L. (1963). Lime clay mineral reaction products. Highway Research Record, Vol. 29, pp 70-82.

SOFRA F., BOGER D.F. (2001). Slope prediction for thickened tailings and pastes, Proceedings of 8th Int. Conf. Tailings Mine Waste. 